\title{
Geopolitics of the colonial prison island: The case of Poulo Condor (Con Dao)
}

\author{
Sophie Fuggle \\ Nottingham Trent University, UK \\ sophie.fuggle@ntu.ac.uk
}

\begin{abstract}
This article takes up the specific example of Poulo Condor (the Con Dao archipelago in Vietnam) as colonial prison island in order to examine this persistence of colonial island imaginaries built around the imagined project of the prison island well into the middle of the 20th century. Such imaginaries appear to run counter to dominant political discourse of the period along with ongoing media campaigns calling for the end to penal transportation and overseas penal colonies. This article contends that closer attention needs to be paid to the disjuncts and gaps between the official discourse of the French colonial authorities located in France and the enactment of such discourse in the colonies themselves. The central focus of the article is a close analysis of correspondence between colonial officials stationed in French Indochina from 1925 onwards; these documents will be contextualised with reference to the longer histories of both the Con Dao archipelago and France's use of prison islands. An understanding of Poulo Condor as a complex extralegal space will be framed by Ann Laura Stoler's concept of the 'colony' as it develops Giorgio Agamben's notion of the 'state of exception' and Michel Foucault's concept of 'security'. What emerges is an ongoing colonial pathology which continues to fixate on the prison island as a key colonial stake even after such a stake has become increasing untenable.
\end{abstract}

Keywords: colonialism, Con Dao, penal colonies, Poulo Condor, prison islands, Vietnam https://doi.org/10.24043/isj.152 • Received February 2020, Early access February 2021

(C) Island Studies Journal, 2021

\section{Introduction}

If we want to maintain a penal colony [bagne] on POULO CONDOR there is only one solution which is to turn it into the penal colony of the Union Française [...] This would be as utopian as it would be apolitical. (Michel, 1948) [Unless otherwise stated all translations from the original French are the author's own]

The above statement appeared in a note addressed to the High Commissioner of Indochina, Emile Bollaert, from his political advisor Didier Michel, dated 18 February 1948. It forms part of an ongoing discussion between the High Commissioners (first Bollaert and then Léon Pignon) and their advisors about the future of the French colonial prison island Poulo Condor (Con Dao) located $200 \mathrm{~km}$ off the southern coast of Cochinchine. The statement is 
particularly telling in its articulation of a continued colonial investment in the island qua penal colony at a point when France had not only been obliged to acknowledge its shifting, reduced role in Indochina but was also in the final stages of closing its largest penal colony in French Guiana, having ceased convict transportation in 1938. The use of the term 'utopian' is unusual at this point not least as it is usually associated with much earlier visions of the larger penal colonies in French Guiana and New Caledonia modelled on the perceived successes in Australia (Forster, 1996).

Similarly, to define such a project as 'apolitical' seems especially odd in the context of a prison island used to house those convicted of anti-colonial (and later, communist) activities alongside common-law criminals. Michel's comment might easily be dismissed as throwaway and misjudged. However, when read in the context of the wider correspondence from this period, it becomes clear that during the final years of French colonial occupation in Vietnam, the small Poulo Condor archipelago, of which Grande-Condore (Côn Sơn) is the largest island, played a key role in maintaining colonial fantasies, themselves predicated on the concept of the prison island as penal colony.

Drawing on archival documents now housed in the Archives Nationales d'Outre Mer in Aix-en-Provence, this article considers this specific geopolitical role played by Poulo Condor during the late 1940s. The island was used as a French colonial prison from 1862 onwards and became notorious for its particularly harsh conditions which, at various points, included the use of torture and infamous French penal technologies such as the 'barre de justice' (a long metal bar to which prisoners would have one or both legs shackled), an export from the old dockyard prisons (Pierre, 2017). Over 20,000 prisoners are thought to have died on Poulo Condor over the course of its operation (Nguyễn, 2012). This is an extraordinary total given the island only housed an average of about 2,000 prisoners (only increasing to 10,000 during the American War) at any given time. The irony whereby Con Dao became a key site of political education, producing some of Vietnam's most renowned political leaders, including its second President, Ton Duc Thang, who spent 15 years imprisoned there, has been well noted by scholars (Goscha, 2011; Marr, 2013; Zinoman, 2001).

The present article takes up the specific example of Poulo Condor as colonial prison island in order to examine this persistence of colonial fantasies built around the imagined project of the prison island well into the middle of the 20th century. I adopt the term 'fantasy' here alongside 'pathology' as context-specific forms of what Kothari and Wilkinson (2010) have termed 'colonial island imaginaries', drawing on Edward Said's broader notion of 'colonial imaginaries'. These imaginaries refer to the projection and construction of multiple aspects of island life, landscape, resources, location, landscape, and so on as befit various colonial projects. Such imaginaries, while often relying heavily on myths and binaries, are nevertheless multi-faceted and subsequently open to reconfiguration by different populations and groups over the course of time and, indeed, decolonisation. Conversely, the fantasy of the prison island that this article seeks to unpack is based on a particular refusal to accept the colonial project as winding down and a conception of island space that reflects the heavy (yet grossly underfunded) use of incarceration throughout French colonial occupation of Indochina (Zinoman, 2001, p. 63).

Such fantasies might appear to run counter to dominant political discourse of the period along with ongoing media campaigns calling for the end to penal transportation and overseas 
penal colonies. What this article contends is that closer attention needs to be paid to the disjuncts and gaps between the official discourse of the French colonial authorities located in France and the understanding, negotiation, and enactment of such discourse in the colonies themselves. Rather than consider such gaps as anomalies or the result of individual acts of interpretation, we might instead posit that it is precisely these gaps or elisions that define the colonial operation in its essence. This approach echoes Roscoe's (2018, p. 63) call to attend to the "view from the colonies" which she explores in relation to the use of carceral islands off the coast of Australia both during and after the cessation of convict transportation from Britain to the mainland.

The transitional moment from French colonial occupation to withdrawal might also be compared with that identified by Sherman (2009) in her analysis of the changing role and status of the penal settlement located on the Andaman Islands between 1921 and 1940. Indeed, as shall be noted later, the Andaman Islands were held up by French colonial authorities as a key example of ongoing use of penal colonies by the British. Sherman's discussion of the shift to voluntary transportation following WWI emphasizes tensions between the dual colonial ambitions of discipline and development along with those of central and provincial government. What is absent from the archives that form the basis of my analysis is any aspiration towards the development of Poulo Condor beyond its function as penal colony.

This article will begin by setting out a brief history of the archipelago and, in particular, the various appellations by which it has been known. We will also identify the presentation of Poulo Condor within the French colonial imaginary as both a 'tabula rasa' and a space that has always operated as a site of exile and imprisonment. The article then goes on to explore the 'exceptional space' of the prison island via Ann Laura Stoler's $(2012,2016)$ reading of Michel Foucault and Giorgio Agamben, focusing in particular on Foucault's (2009) oft-overlooked notion of 'security'. This is intended to create a helpful theoretical framework within which to consider in detail some of the correspondence between colonial authorities based in Indochina towards the end of French colonial occupation concerning an imagined future for Poulo Condor. By way of conclusion, the article offers a snapshot of the archipelago today as both a space of collective memory and of luxury resort tourism. The vestiges of the French colonial prison buildings are considered alongside the more recent American camps in order to draw out the carceral and colonial continuities that play out in the space of the island.

While the specific, complex political events taking place in Indochina during the 1940s and 1950s determine to a large extent the use of the prison island in the detention of so-called "political prisoners", this article also looks at the longer term political imaginary of the prison island and specifically its definition as bagne, the shorthand term adopted by the French to refer to its penal colonies. The correspondence between High Commissioners of the period, Bollaert then Pignon, and their advisors, provides clear evidence not simply of the strategic geographical position of Poulo Condor but of ongoing colonial ideals around the role and significance of the prison island. Where the arrival of the U.S. forces in the 1950s and the subsequent full withdrawal of the French made such colonial fantasies untenable, the persistence of these up until that moment merits attention.

Secondly, in considering the language used to describe the geopolitical function of the island in this correspondence, this might be mapped back onto a wider context in which France's main penal colony in French Guiana was in the process of closing. While there is potential for further analysis of Poulo Condor as archipelago in relation to France's other main overseas 
penal colony in New Caledonia, this is beyond the scope of the present article. The penal colony in New Caledonia stopped receiving convicts in 1896 and ceased operation in 1924 (Barbançon, 2003). Furthermore, despite its island geography, New Caledonia bears little resemblance to Poulo Condor in terms of size, topography, or climate. Indeed, Poulo Condor $\left(76 \mathrm{~km}^{2}\right)$ is closer in size to L'île des Pins $\left(152.3 \mathrm{~km}^{2}\right)$, located $150 \mathrm{~km}$ to the east of the New Caledonia mainland and once used as a prison island for both communards and Kabyle rebels.

Where on the one hand, the divergence in discourse around the two bagnes demonstrates a disjunct between Paris and its colonies, it also suggests we consider more carefully the reasons why the bagne was closed in French Guiana, looking beyond the usual humanitarian arguments to consider the highly racialised stakes of transportation. In turn, this provides useful pause for reflection on the persistent use of extra-territorial islands (Horn, 2019; Loyd \& Mountz, 2018; Ratuva, 2019) as sites of imprisonment, internment, and detention today, alongside the difficult political task of decarceration (Fuggle, 2019; Heiner, 2015; Kennedy, 2014) within contemporary contexts.

In juxtaposing the wider history of the bagne with the specific story of Poulo Condor at the end of French colonial occupation of Indochina, previously imperceptible gaps in existing scholarship appear. Both Morlat's (1990) work on colonial repression and Zinoman's (2001) extensive study of French colonial prisons in Vietnam conclude in the early 1940s and, as such, do not consider the complex transition from French to American occupation. Where Zinoman's epilogue (2001, p. 302) includes a throwaway indictment of the re-education camps, any mention, for example, of the French use of tiger cages and their American equivalent is glaringly absent. Similarly, Zeller's (2019) recent account of the Japanese occupation of 1945 dedicates a chapter to the "tiger cages" used to imprison French and Vietnamese subjects. Not only does Zeller (2019, p. 167) fail to acknowledge the use of the same methods by the French colonial authorities which pre-existed the Japanese occupation, he emphasizes the concept of "caging" prisoners as symbolising a system put in place by the Kenpeitai. Finally, Angleviel's (2020) recent study dedicated to Poulo Condor considers the American use of the archipelago but overlooks the archives from the 1940s discussed in this article.

Considering the wider context of France's use of convict transportation, DonetVincent's (1992) account of the end of the penal colony in French Guiana lays much of its emphasis on the work of Charles Péan and the Salvation Army rather than the wider geopolitics of transportation. Her approach is to define the closure in terms of Péan's painstaking humanitarian work in the colony which she offsets against Albert Londres' (1924) investigative journalism originally published in Le Petit Parisien. As such, the closure of the penal colony is recounted as a story involving different types of social actor. Moreover, while Donet-Vincent documents the debates around the penal colony and its proposed closure in metropolitan France during the 1920s and 1930s, less focus is given to the ongoing role of colonial prisons elsewhere, including Indochina. Recently, former French Minister of Justice - and outspoken critic of both the death penalty and France's prison system - Robert Badinter (2017, para. 2) has called for more attention to be given to the operation of the bagne during Vichy, which he describes as "a veritable hecatomb" and a crime against humanity (on the impact of the Vichy regime in French Indochina see also Jennings, 2001). Further comparison between the Nazi regime and the forest work camps in French Guiana, notably Charvein, has been made by Cornuel (2003). Yet, despite calls for greater accountability and acknowledgement of the atrocities associated with penal transportation as a global 
phenomenon (Anderson, 2018), little has so far been done to incorporate other French colonial prisons during the post-WWII period into this analysis.

\section{A short history of Con Dao}

To start to understand the complex political imaginary of Con Dao, it is useful to look briefly at its various appellations. As Nash (2016) argues, the role of place-naming is key to grasping the geopolitical stakes of an island or archipelago. The different names used to refer to Con Dao and their respective etymologies not only emphasise the multiple claims made on its space throughout history but also suggest the impossibility of easy, fixed definitions of the archipelago. The geopolitical value of Con Dao as a strategic point for explorers throughout history can be traced via clear references to the archipelago from Marco Polo in the 13th Century onward (Polo, 2016/c.1300, Book 3, Chapter 8). It is also possible that even earlier references can be found in Ptolemy's Geography where a group of three islands are mythologized as the Isles of the Satyrs. In his 1764 Origin of Commerce, Adam Anderson's location of the islands referred to by Ptolemy are more precisely situated in relation to Malacca as part of a critique of Ptolemy's erroneous and fanciful map-making attempts:

And, to demonstrate how little they knew either eastward or north-eastward of the Aurea Chersonesus, i.e. probably the promontory of Malacca, Ptolemy has placed thereabouts the three fabulous Isles of the Satyrs, wherein they supposed the inhabitants to have tails like beasts; and that ships having any iron nails fastened in them were stopped in the neighbouring seas of those isles, and could not proceed, on account of the rocks of loadstone or magnet at the bottom of the sea. (Anderson, 1764, p. lxxvi)

There is little historical consensus on the number of islands making up the archipelago, with the total suggested ranging from the three referenced by Ptolemy all the way up to the current official list of 16, consisting of the following: Côn Sơn (previously Grande-Condore), Hòn Bà (Petite-Condore), Phú Hòa, Phú Lệ, Phú Phong, Phú Vinh, Phú Nghĩa, Phú Thọ, Phú Bình, Phú An, Phú Hưng, Phú Thịnh, Phú Hòa, Phú Hội, Trứng Lớn, and Trứng Nhỏ. A 1953 report by the French colonial authorities entitled FICHE sur les possibilités de l'utilisation de l'archipel de POULO CONDORE suggested there were only 10 islands (Commissariat Général de France en Indochine, 1953). While all the islands have multiple names, many of the smaller islands are little bigger than large rocks with surface areas of less than $100 \mathrm{~m}^{2}$.

'Pulo Condore' was the name given to the archipelago by the British East India Company, who set up a short-lived and fateful garrison on Con Son Island between 1702 and 1705 (Wong, 2012). The word 'pulo' is a variation of the Malay pulau, meaning 'island'. 'Condore', with its multiple spellings, is said to refer to the largest island's gourd-like shape. The story of the brief British occupation is recounted not without a certain relish by Demariaux (1956) as part of his reportages on the islands in the 1930s published in La Depêche Indochine. His account of the failure of the British to successfully develop long-term strategic use of the islands, despite clear intention to do so, is no doubt intended to lay emphasis upon 
the importance and effectiveness of the French colonial occupation of the island beyond its use as a prison. However, as we will argue, one of the difficulties faced by the French by the end of their colonial occupation was imagining the island as anything other than a prison.

Another possibility is that the island's name evolved from the mythical Chinese place known as Kunlun (on conceptions of islands in Ancient and Imperial China, see Luo \& Grydehøj, 2017). Kunlun Shan means 'mountain range' in Mandarin, and it is likely that Con Dao's mountainous terrain inspired the appellation "Kunlun Shan Islands" marked on the 17th century Mao Kun navigation map compiled in 1628 by Mao Yuanyi which is now housed in the U.S. Library of Congress. Penitentiary director Jean Brule (1947), in his short book on the island, suggests a variation of the transliteration of the Chinese K'Ouen Louen, subsequently transformed into Con Non by the Annamites, meaning 'island of snakes'.

Variations on Condore (Condor, Kondor, Condur, Sondur) have existed at least since Polo's visit in 1292 but, from the end of the 19th century onwards, the name became inextricably associated with French colonial occupation. The French version, 'Poulo-Condore', functioned (and continues to do so) as a metonym for the prison established in 1861. The French would also refer to the islands collectively as 'Les Condores' and sometimes the largest island Con Son becomes 'Grande Condore', with Hòn Bà, the largest of the smaller islands located South West of Con Son, known as 'Petite Condore'. A travel memoir dating from 1723 (Mémoire sur l'isle de Poulo Condor surnommée isle d'Orléans en Chine, 1723) suggests an earlier attempt to rename the largest island "Isle d'Orléans en Chine" but this does not seem to have taken hold, indicating perhaps the persistence of the archipelago's existing appellations amongst the different populations in the region. French occupation of the islands dates from the treaty of 28 November 1787, which is reaffirmed by a subsequent treaty dated 5 June 1862. As will be discussed further, it is toward these documents that the colonial authorities in Indochina turn during the late 1940s in order to assert a colonial presence on Poulo Condor which exists independently to the wider French colonial occupation of Indochina (Wintrebert, 1948).

It is not clear exactly when the shift from the French 'Poulo-Condore' to the Vietnamese 'Con Son' took place, but it is likely to have occurred in the mid- to late-1950s during the French withdrawal from Indochina. CIA bulletins dating from the mid-1960s indicate the archipelago on their maps of Vietnam as "Con Son" with "Poulo-Condore" marked in brackets (Central Intelligence Agency, 1965) and, by the 1970s, the island is unequivocally referred to as Con Son (Department of State, 1970). Consequently, today it seems that to evoke Con Son, even when referring specifically to the largest island in the archipelago, is to make allusion to the horrors of the American War in the same way that to speak of Poulo-Condore constitutes a direct reference to the French prison once located on the island. As a consequence, Con Dao seems to have become the preferred term for talking about the island(s) in the present tense in both tourist literature (Lonely Planet, 2018) and general conversation in Vietnam.

Zinoman (2001, pp. 16-17) has suggested that the architecture, management, and general "ill-discipline" of Indochina's colonial prisons emerged from a number of factors which included lack of economic investment and a refusal to consider colonial subjects in terms of European discourses of reform and rehabilitation. Yet, it is also worth noting the concept of the prison island as one which initially appeared off the French coastline as part of Vauban's ceinture de fer (iron belt) fortifications around the French coastline between 1665 and 
1707 (Fougère, 2002, pp. 36-38). The carceral uses of France's islands document the shift over the centuries from a form of security directed outwards towards external threats to one facing inwards towards internal enemies. Most famous, perhaps, is the Île d'If, where the fictional Count of Monte Cristo was held along with real life communards. More recently, the disgraced Vichy leader Philippe Pétain was exiled to the Île d'Yeu after his death penalty was commuted due to old age. Between 1959 and 1961, future Algerian president Ahmed Ben Bella was imprisoned at Fort Liédot on Île d'Aix along with four other FLN (National Liberation Front) members. Since the 17th century, France's coastal islands have also functioned as holding pens for those awaiting deportation and transportation. Convicts awaiting transportation to French Guiana were held in the Maison Centrale on Île de Ré, located off the Atlantic coast next to La Rochelle. The prison still operates today and houses those undergoing some of the longest sentences in France.

The complex mythology of Poulo-Condore embodied in the etymology of its name is doubled by its role as 'bagne'. How do we understand this term which is applied to Poulo Condor not merely as a nickname but as a designation - one that is clearly marked on the prison wall in a postcard dating from the early 20th century - and sets it apart from other forms of colonial prison such as the 'maison centrales' found in Saigon and Hanoi? The term bagne was most widely used in France to denote the dockyard prisons (bagnes portuaires) located in Brest, Toulon, and Rochefort during the $18^{\text {th }}$ and $19^{\text {th }}$ Centuries. The name was subsequently transferred to the newly established penal colonies in French Guiana and New Caledonia. The first convicts were transported to French Guiana in 1852, and the planning and opening of the penal colony in New Caledonia a decade later coincided roughly with the establishment of the penitentiary on Poulo Condor in 1861.

While the name bagne is generally thought to have originated from the Italian word bagno in reference to the public baths located near the prison in Constantinople during the 16th century where Spanish and Italian Christians were held captive, in his etymological enquiry into the origins of the term, Audisio (1957) has pointed out that the use of the term goes back much further to the Middle Ages. He suggests it was used to refer to the Mahomet slave prisons of the 15 th century and earlier. He also suggests the term bagne in its evocation of 'bain' might be as much symbolic as denoting a specific proximity to public baths or any other body of water. While conceding this is speculative, it is interesting to note the idea of the bagne as a site of cleansing and, indeed, spiritual redemption - and this was, in fact, part of the rationale for creating the penal colonies in French Guiana and New Caledonia (Fougère, 2002, p. 130). Yet, such symbolism, however implicit, was largely at odds with the existing image of the dockyard prisons as sites of overcrowding, petty and organised crime, and general insalubrity from which the name was directly taken. As Fougère (2002, p. 130) points out, care was taken to distinguish the overseas 'colonies pénales' from the 'bagnes portuaires' (dockyard prisons), not least via a focus on the "agricultural myth" that emphasized redemption via working the land.

Moreover, it is important to observe that where France's main penal colonies assembled political deportees, transportees (those having committed serious and violent crimes), and relégués (repeat recidivists) from both the Metropole and its colonies, the utopian vision of the penal colony as a site of redemption was largely reserved for the white population transported from mainland France. As Paterson (2016, p. 223) has pointed out: 
The rhetoric of rehabilitation - and regeneration - was central to French prisoners being deported. Arguably this was merely rhetoric, but even as a rhetorical stance it differed from the version applied to Indochina, where no discourse of rehabilitation existed, just containment or extraction of labor, or both.

Thus, the "bagne" on Poulo Condor should be understood as a site of exile which combined both forced labour and political deportation. It was also based on earlier practices including the exile of subjects from their home village and region. Where this occurred to fulfil labour requirements elsewhere, it not only enacted a rupture in terms of material, economic support, it also constituted a spiritual and symbolic form of severance as a result of the importance attached to homeland across Vietnamese culture and society (Paterson, 2016, pp. 222-223; Zinoman, 2001, pp. 17-18).

According to Jean Brulé (1947), director of Poulo Condor during 1947 and 1948, many of the files and archives located on the island were destroyed when prisoners briefly took over the island during 1945-46. His own short text dedicated to the prison is heavily reliant on the journalist Jean-Claude Demariaux's reportages which appeared in La Dépêche d'Indochine almost a decade earlier (Brulé, 1947; Demariaux, 1956). The aim of the present article is not to provide a full, in-depth account of Poulo Condor during its 113-year operation; Zinoman's 2001 study already offers an extensive account of the French colonial prison system in Vietnam up until 1940. Instead, the intention is to identify what might be considered a blind spot in other historical accounts. In his presentation of the "archives de la guerre" (archives of war) for the period between 1945 and 1947, Devillers (1988) takes the approach of allowing the public discourse and private correspondence to largely speak for itself. He concludes with the scathing indictment of all involved in what he terms the "civilizing and revolutionary myth," (Devillers, 1988, pp. 376-7) arguing, in particular, that the bogus anti-communist stance assumed by the colonial administration could not fail to lead to U.S. intervention and the widespread violence that ensued. If his selection of material is focused on the grand narrative of the French Indochina war, our focus here is on the somewhat lesser known details of Poulo Condor as key geopolitical stake.

Scholars looking at colonial prison islands (Roscoe, 2018) and other spaces of carceral exile such as the infamous Boven Digoel detention camp in the Dutch East Indies (Mrázek, 2009; Shiraishi, 1996) have argued that these exceptional spaces need to be understood as actually representing microcosms or microgeographies of wider colonial occupation. In isolating textual fragments from the available archives for close reading, this article advocates for a form of textual practice that repositions the archipelago at the centre rather than the periphery of mid-20th century colonial debates. The absence of extensive archives and the fragmentation of those archives that do remain is telling in itself and feeds the mythology of Poulo Condor in the political imaginary of the 1940s and 1950s, during which time many of the reports emphasise a lack of prior information on the archipelago as a starting point or context for strategic reflections. A note accompanying the aforementioned 1953 report on the archipelago dated 26 October and sent by Lieutenant-Colonel Adrieu to the Secretary of State makes the following pronouncement:

The documentation at our disposal in Indochina on Poulo-Condore is very limited. Very few documents have been found, a file produced following an inter-army 
reconnaissance between 28 and 21 March 1949 has provided the basis for what follows. The Navy possess no monographs with the exception of a hydrographic analysis included as an annex. (Adrieu, 1953)

Co-opting the geographical remoteness of the archipelago (Hayward \& Tran, 2014), this perspective allows for a geopolitical reimagining of the island which simultaneously emphasizes the island's long history as a site of imprisonment whilst presenting it in terms of a tabula rasa (Duschinsky, 2012) upon which colonial fantasies (or indeed, pathologies) might continue to be projected. In exploring the persistence of such fantasies, the present article develops existing work carried out by Éric Fougère (2002) on France's wider history of prison islands and might be situated alongside more recent debates about the ongoing legacies of colonialism on island geographies (Amoamo, 2013; McMillan, 2019).

\section{State of exception}

While establishing sovereignty on an island seems straightforward due to its separation from larger bodies of land, as Benton (2009) has pointed out in relation to an earlier period of European colonial history, its management is often incredibly complex. Where an island is too small to form its own administrative domain, it must invariably be attached to one located on the mainland. Con Dao is today part of Bà Rịa-Vũng Tàu province, located some 230 $\mathrm{km}$ away. Where islands operate as penal settlements for multiple jurisdictions, there is the more complicated question of who pays for the housing and subsistence of its detainees. Such questions inevitably become more pronounced and more contentious during the transition from colonial government to independent rule.

In exploring the shifting geopolitical stakes of Poulo Condor as bagne or colonial prison island at the specific point towards the end of France's colonial occupation of Indochina, our approach draws on Stoler's (2012) critique of the "postcolonial" and the writing of histories of "colonialism". Stoler (2012, para. 6) identifies a tendency of political theory to focus on "colonisation" or "colonialism" without seeking to understand the complexity of the term "colony":

None of these points of entry [ways of saying what a colony is] broach the changing force fields in which the term "colony" has operated, nor the geo-political and historical breadth of the political visions embedded within it. Each assumes an essence rather than tracks its coordinates, ascribes rather than poses what a colony is, and what generates and makes up its multiple logics. Such starting points are poorly positioned to address a colony's range of mutation. Not least, a foundational if shadowed feature is lost: namely, that the colony (the penal colony, the military colony, the settler colony, the 19th-Century agricultural colonies in France) is marked by the instability of both its morphology and the political mandates to which its architects and agents subscribe.

It is these multiple logics that embody the bagne in Poulo Condor together with its shifting status in relation not simply to mainland France or Cochinchine but to other bagnes as well as other French colonies and, subsequently, overseas territories demanding convict labour from 
Indochina. Moreover, in identifying the violence embedded in the decolonial process, it is also important to explore the way in which such violence is underpinned by colonial administrative processes. Such processes might be read generously as desperate attempts to cling onto colonial power via recourse to multiple, conflicting decrees and the legal entanglements to which these gave rise. A note addressed to the High Commissioner of Indochina dated May 1948 and signed "Brossard" concerning the future of Poulo Condor includes the thinking through of multiple options or projects for the island's future (Brossard, 1948). Here, the archipelago is described as a "gage territorial sur," and we might identify a deliberate ambiguity in the choice of the term 'gage' which can mean bet or wager but can also mean token or forfeit. Assuming both meanings are implied, Brossard seems to be suggesting the islands are worth investing in (betting on) but also that France's claim to the territory is a certainty since the archipelago was handed over to the French (forfeited) by Emperor Gia-Long in 1787 in exchange for military support. While we might now disagree as to the validity of treaties and decrees attesting to French sovereignty in overseas territories, in the mid-20th Century, referral to such documents in the face of anti-colonial opposition would have been considered by the French colonial administration as both an honest and legitimate affirmation of long-term property rights (Wintrebert, 1948).

Alternatively, we might also read this use of bureaucracy as effective and deliberate in producing a political impasse, the only response to which was ultimately violent resistance. In other words, the only possibility for anti-colonial struggle in the face of the complex administrative web spun by French colonial occupation in Indochina was the seizing of power by force. In this respect, the South Vietnamese government could only ever defer to the bureaucratic structures and systems the French had left in place. Conversely, any direct opposition could be met with an extralegal response backed by both the colonial military and carceral infrastructures in place across Indochina. Following the reinstatement of French colonial authority of the penitentiary in 1947, an inevitable tension arose between the federal direction of the bagne (the director Jean Brule reports to the High Commissioner) and the South Vietnamese government whose oversight of Cochinchine included Poulo Condor. The budget for the penitentiary came out of the government budget with costs related to prisoners from other parts of Indochina reimbursed. On 22 September 1946, the French Commissioner in Cochinchine, Jean Cedile, writes to Nguyễn Văn Thinh, President of the provisional government in Cochinchine, addressing this issue (Cedile,1946). The response from the President, dated 14 October 1946, is frosty and insists that the administration of the islands falls within the government's jurisdiction (Nguyễn, 1946). Implicit in this request, which is subsequently ignored, is a refusal to recognise French sovereignty over the islands independent to their colonial occupation of the mainland.

The case of Poulo Condor is doubly relevant in suggesting this strategy of bureaucratic impasse on the part of the colonial administration. In this sense, the dossier marked Problemes politiques actuels de Poulo-Condore (Haut-Commissaire de France pour l'Indochine, 1946-1949), which contains correspondence from 1946-1949, identifies the archipelago not as a problem to be "solved", despite this claim being made, but instead as a problem to be instrumentalised. This is evident throughout the archives dating from the period which include the suggestion made by the Minister of France's overseas territories, quoted in a note circulated amongst colonial officials in September 1948 that the penitentiary might be reserved for those 
sentenced for carrying out anti-colonial violence (Haut-Commissaire de France pour l'Indochine, 1948). An earlier letter sent from Buttin to the High Commissioner of Indochina in May 1948 acknowledges that any proposals made concerning the future of Poulo Condore would not be readily agreed upon by the South and Central Vietnamese governments or treated lightly by the press in Saigon (Buttin, 1948). Consequently, any proposed projects for the archipelago required carefully handling and emphasis on its exceptionality. If the desire to maintain sovereignty over Poulo Condor was the direct result of the archipelago's natural resources and potential for development, this position would seem logical. However, the failure of the penal colony to sustain itself via agricultural production makes this possibility moot. Rather, the interest in islands consists in their operation as site of colonial repression. The complex legalities of the space lies not merely in their islandness and distance from the mainland but, more specifically, in the extralegal status of those imprisoned there.

Poulo Condor has always constituted that which Agamben $(1998,2005)$ following Schmitt (2005/1922) has identified as a state of exception. According to Benton (2009, p. 171), there are numerous elements of uncertainty that "tend to inscribe extrajudicial actions into the heart of systems of exile and convict transportation." In the case of Poulo Condor, this exceptionality is, moreover, particularly impressive in its multi-directionality. As Stoler (2016, p. 116) points out:

Colonies, like camps, are predicated not always on the making of "bare life" but on the arbitrary and quixotic shift in technologies that unevenly suspend rights, sustain privation, and diminish capacities for political life. But the suspension of rights is not the suspension of law.

The law was not simply suspended to permit extralegal forms of punishment, deprivation, and, ultimately, torture and execution. At other points in Poulo Condor's operation, the law was called upon as a means of redefining those involved in anti-colonial struggle as common criminals. Specific acts of violence or destruction of property were judged as criminal rather than political acts in order to facilitate transportation of Vietnamese convict labour to France's other overseas colonies.

Many of Indochina's convicts transported to French Guiana in 1931 were transferred from Poulo Condor, where they had originally been classed as political prisoners. The transfer was intended in part to deal with overcrowding in French colonial prisons across the region, as well as to remove a sizeable portion of anti-colonial actors from Indochina. Back in October 1925, André Hesse, Minister of the Colonies, had written to the Governor of Indochina having been made aware that various colonial subjects (he does not say which colonies specifically) accused of political activities had been detained in regular prisons (maisons d'arrets and maisons de force) (Hesse, 1925). The minister emphasises the requirement to apply a different level of treatment to political prisoners than that applied to regular criminals, and this is clarified via a summary of the specific material conditions which includes larger cell space, greater freedom of movement, and better quality of food to regular prisoners, as well as choice of clothing and access to visitors. Hesse also emphasizes the need to budget appropriately for these considerations and to ensure common and political prisoners are kept separate. However, an interesting point is made in a subsequent clause: 
What causes a prisoner to be considered as a "political prisoner" is evidently the nature of the infraction or crime for which he has been pursued. In France, during certain periods, certain crimes (carried out by anarchists, acts pertaining to the external security of the State, intelligence sharing with the enemy) have been considered too serious to grant the political prisoner a favourable regime. There are still, however, exceptions which can and have always been considered inevitable. The administrative authority conserves from this point of view within its purview a discretionary power of assessment. But we can affirm that the qualification of a crime or infraction as political should inspire a wide and generous understanding, when it relates to acts arising from passions engendered by electoral struggles. (Hesse, 1925)

It is not difficult to envisage how this reference to potential exceptions provides license to revoke the special privileges of any and all potential political prisoners via any perceived threat such activity might make to internal and international security since surely, by its very definition, subversive political activity which results in arrest and detention is precisely that which poses a threat to existing national and international regimes. However, this exceptionalism is framed within a discourse that presents French colonial administration as open and liberal in its sentencing practices. Again, the irony whereby such instruction can be interpreted in terms of the global perspective offered by transportation between colonies is clear.

At least 80 of those deported to French Guiana in 1931 had been involved in the Yen Bay mutiny of 1930. Since political deportees sent to French Guiana were usually exempt from labour according to the political decree of 1850, this status had to be revoked to ensure the maximum labour force possible. Anyone who had been arrested on suspicion of specific acts of violence or property damage was re-classed as a common criminal. This was not simply a sleight of hand but was written into legal codes (cited in Pagès, 1937).

The state of exception reaches its apotheosis in the late 1940s and early 1950s. Where the implication of exceptional use is that it will be limited and carefully applied, what the 20th century has taught us, if anything, is that the concept of the 'exception' offers up a catchall definition that simultaneously depoliticises certain forms of political protest whilst enacting a hyper-politicisation of others. When Michel (1948) refers to the bagne as "apolitique" (apolitical), this is perhaps what he is alluding to. Moreover, it assumes an evolution of the bagne from its original role (at least as defined by the Metropole) as a certain form of colonial institution which affirmed strict distinctions between political deportees and transported criminals. 'Apolitical' therefore describes not an absence of politics but the ability to suspend and redefine political and legal categories. Michel's (1948) attribution of "utopian" is less clear, but we might read this in terms of a new vision that moved beyond old ideas of the bagne to a new phase in its evolution. Here, we might draw on Stoler's $(2012,2016)$ analysis of the "colony" predicated on Michel Foucault's (2009) notion of "security." Although security is not a term Foucault appears to develop beyond his 1978 lectures, it provides the counterpoint in both scale and directionality to disciplinary modes of power. Where such modes target the individual body and seek to fix it within a certain organisation of space and time, security is predicated on mobility and growth. It is centrifugal rather than centripetal (see also Fougère, 2002, p. 159). Foucault (2009, pp. 17-18) describes the shifts in town planning which allowed for growth rather than sought to contain the city within clearly delineated walls and limits, citing projects for the redevelopment city of Nantes conceived 
around the idea of flows. In contrast to discipline, security is focused on future potentialities rather than existing problems:

Discipline works in an empty, artificial space that is to be completely constructed. Security will rely on a number of material givens. It will, of course, work on site with the flows of water, islands, air, and so forth. [Second], this given will not be reconstructed to arrive at a point of perfection, as in a disciplinary town. It is simply a matter of maximizing the positive elements, for which one provides the best possible circulation, and of minimizing what is risky and inconvenient, like theft and disease, while knowing that they will never completely be supressed. (Foucault, 2009, p. 19)

Where Agamben (2005), developing the concept beyond Foucault's lecture series, has claimed that security is the dominant paradigm today, Stoler (2016, p. 77) considers security as embedded in colonial practice and administration from a much earlier date and key to understanding the colony and its operation: "The colony as a political concept is in part defined by its potentiality." To speak of the prison island as "utopian" not only embodies earlier colonial desires constructed around the vision of the bagne. However, rather than locating the prison island within this vision as self-contained and centripetal in its organisation of convict bodies, Poulo Condor is instead imagined as a starting point for a de-centred and centrifugal form of colonial operation.

\section{The persistence of colonial pathologies}

It is in this context that we should read the correspondence between Jules Brévié, Governor of Indochina, and Pierre Pagès, Governor of Cochinchine on the question of Poulo Condor and the role of the bagne in 1937. As part of the lengthy report submitted by Pagès to Brévié on 22 March, the following observation is made as to the ongoing relevance of the penal colony:

I note, here, the appropriateness of maintaining for the colonies - even as a transitory measure - the exile of convicts, in such a way that does not diminish the exemplary character which dictates its utilitarian and social role too often here for us to cease to recognise it. (Pagès, 1937)

In this respect, Pagès continues, the bagne is seen as part of an ongoing "mission civilisatrice" (civilising mission) aimed at gradually replacing oriental values with Western ones: "Only a slow and careful adaptation will see Western conceptions eclipse those of the Orient." To back this up, he cites the example of the Andamans, used by the British as a colonial prison for Indian subjects until 1932. This use of the colonial prison island long after transportation of British convicts ceased is presented as part of a successful long game played by the British which could be emulated with comparable success by the French not only in Indochina but via the location of other sites within the French Empire such as the Marquis Islands:

It is towards a similar goal that we should be aiming. And I would like to propose, to that effect, that the Department undertake the relegation of convicted 
Indochinoise to the valley of Vaithu and the Island of Noukahiva in the Marquis Islands, a region which is classed as one of the healthiest in the Tropics.

Only a measure of this nature will provide relegation with a rational organisation. (Pagès, 1937)

While such suggestions are dismissed by Brévié in his response which briefly explains the various impracticalities of such a vision of transportation to the Marquis Islands, it is interesting to note the ongoing comparison with British use of penal colonies and colonial prison islands which constituted the founding rationale for the French overseas penal colonies almost a century earlier (Brévié, 1937). Moreover, with the end of metropolitan transportation in sight, a reconfiguration takes place which shifts Poulo Condor from the periphery to the centre as, in Pagès' reflections, it becomes the starting point for further future possibilities of transportation beyond Indochina and to the maintenance of a colonial penal project that places the remote prison island at its core.

\section{Conclusion: Carceral continuities}

The strategic importance of Con Dao is evident in the various colonial expeditions carried out during the 17th and 18th centuries as well as its complex etymology which suggests it also inspired the imagination of neighbouring territories including China and Malaysia. On 15 March 1947, the French colonial newspaper Journal de Saïgon published its column "Les anniversaires oubliés" (forgotten anniversaries) with the subtitle "Un peu de géographie" (a little geography) dedicated to the history of France's occupation of Poulo Condor:

Situated in the South China Sea, opposite the western branch of the Mekong Delta, Poulo-Condore is formed of two small islands. The main, Grande Condor, measures $15 \mathrm{~km}$ by $9 \mathrm{~km}$ with more than a thousand inhabitants. The climate is very hot and humid. The vegetation is abundant. One notices the penitentiary. Petite-Condor is separated from the larger island by a canal which dries up when the tide is out.

Poulo-Condore was given to Louis XVI by the Emperor Gia-Long in 1787 and the penitentiary was closed. The island was occupied definitively by France in 1881.

It was on 1st March 1862, just 85 years ago, that Poulo-Condore became a penitentiary once more and, since then, has housed criminals, thieves [...] those condemned to forced labour. (Journal de Saïgon, 1947)

The timing of this article which purports to be little more than a brief lesson in history and geography is no mere coincidence. Poulo Condor would have been very well known to both French and Indochinese subjects and so they did not need a reminder of its existence and location. What the article is reminding its readership of is France's "right" to the island, as well as the longevity of its function as a prison island which pre-dates the arrival of the French. The article also contains a pointed reference to its population as being composed (with the implication that this has always been the case) of "criminals," "thieves," and "those condemned to forced labour". The intention here is to remove all association of the penitentiary with political deportees whilst highlighting the strategic role of the island in colonial law enforcement. 
Thus, where an article in Troupes Coloniales in 1938 (de Villepoix, 1938), emphasises the archipelago's role beyond its function as a prison, what emerges in colonial discourse a decade later is a geopolitical understanding of the archipelago as indissociable from its role as colonial prison or bagne. Furthermore, the 1953 report undertaken as to the strategic value of the island dismisses the possibility of using it as a strategic military base due to the impracticalities of constructing a runway:

On the whole, Poulo-Condore offers mediocre potential for the construction of a base.

If defence is easy, the small surface area of the plains will entail enormous construction works in order to extend these towards the sea or to create installations sheltered by the rocks.

Interior communication would be very difficult and require the construction of expensive roads due to the rocky terrain and steep slopes.

The possibility of creating runways is limited and only a single runway could be built at substantial cost. (Commissariat Général de France en Indochine, 1953)

Since this was later given priority by the U.S. administration, the dismissal of this possibility seems strange. While it might be explained by different budgets, military strategies, and technologies on the part of the French and the Americans, it also attests to the ongoing investment of French colonial occupation in Indochina in the Con Dao archipelago as penal colony. In this respect, the case of Poulo Condor constitutes an interesting and alternative example of what Manos (2015, p. 58) has called "prison fetishism": "Unlike commodity fetishism, prison fetishism does not conceal an exploitative fracture at the heart of capitalism. Rather, it conceals the state and private industry's rapid disinvestment in life itself."

If you visit Con Dao today, it is possible to take a tour of the different sites once belonging to the French colonial prison. One thing that immediately struck me is the extent to which these sites bear resemblance to the architecture and organisation of buildings used by the penal administration in French Guiana, where the majority of prisoners were housed in 'blockhaus' barracks: large empty rooms featuring stone banks, ever so slightly sloping. Prisoners were further confined via the use of the aforementioned barre de justice. Overcrowding meant that prisoners had difficulty lying flat and often had to take turns lying on their sides. Blockhauses of this type were used in the Camp de la Transportation in SaintLaurent-du-Maroni to house those convicts awaiting trial in the Tribunal Spécial Maritime for infractions such as attempted escape. As such, they constituted extra-judicial accommodation within the 'quartier de reclusion' - the prison inside the prison. Regular accommodation for convicts on work detail in and around Saint-Laurent took the form of barrack-like dormitories where convicts slept in hammocks. In Poulo Condor, however, it appears that accommodation in the blockhaus and the use of the barre de justice was default for prisoners regardless of their status.

Another architectural comparison worth noting is the "tiger cages" found in both the Bagne des Annamites at Montsinéry (French Guiana) and on Con Dao. At the site at Montsinéry, the cells are not described as tiger cages and all that remains are the cell structures; the surrounding building and walkways which allowed guards to observe convicts from above have long vanished (Dedebant \& Frémaux, 2012). While the site has been rendered accessible and is subject to regular clearing of vegetation, the presence of moss and foliage frames the 
cells as ruins of a bygone era. Conversely, on Con Dao, the cells, some of which had been smashed up by the U.S. Army following the visit by Tom Harkin (then a legislative aide) and subsequent Life Magazine exposé (Harkin, 1970), have been reconstructed - complete with mannequins - and it is possible to enter the cells as well as view them from above. Here, the emphasis is on the relatively recent history of their usage. The construction of similar types of cell by the Americans in subsequent decades, now marked on tourist maps as "American Tiger Cages", attests to a carceral continuity whereby the U.S. administration were able to vehemently critique the French use of various penal technologies as part of its colonial regime, yet unproblematically reproduce the same forms of incarceration in the service of its Cold War imperialism.

The possibility of visiting these former sites of incarceration, torture, and execution might easily be located within a burgeoning tourist industry focused on the dark and macabre, aimed largely at the Western consumer in search of the sensational and transgressive. However, while acknowledging such forms of tourism are present on Con Dao, these sites have primarily been reclaimed within a nationalist ideology which celebrates the political education and organisation developed amongst prisoners while incarcerated on Poulo Condor as well as their resistance to forms of torture used by both the French and American occupations. Yet, it might be argued that a darker tourism exists in the development of the island as a luxury tourist resort, at once less accessible and more exclusive than the special economic zone of Phú Quốc, another former colonial prison island turned tourist destination.

\section{Acknowledgments}

Archival research and fieldwork conducted for this article was made possible through generous funding from the UK Arts and Humanities Research Council (AH/R002452/1) and the British Council Newton Mobility Fund (NMGR1180428).

\section{References}

Adrieu, G. (1953, October 26). [Note addressed to the Colonel Chef de l'État-Major Particulier. Note No. 1419/CAB-EMP/D-]. Archives nationales d'outre-mer (HCI 102), Aix-en-Provence, France.

Agamben, G. (2005). State of exception. University of Chicago Press.

Agamben, G. (1998). Homo sacer: sovereign power and bare life. Stanford University Press. https://doi.org/10.1515/9780804764025

Amoamo, M. (2013). Empire and erasure: A study of Pitcairn Island. Island Studies Journal, $8(2), 233-254$.

Anderson, A. (1764). An historical and chronological deduction of the origin of commerce, from the earliest accounts to the present time. A. Millar.

Anderson, C. (Ed.). (2018). A global history of convicts and penal colonies. Bloomsbury.

Angleviel, F. (2020). Poulo Condore: Un bagne français en Indochine. Vendémiaire.

Audisio, G. (1957). Recherches sur l'origine et la signification du mot "bagne". Revue Africaine, 98(452-453), 363-380. 
Badinter, R. (2017, November 24). Le bagne de Guyane, un crime contre l'humanité. Le Monde. https://www.lemonde.fr/idees/article/2017/11/24/robert-badinter-le-bagnede-guyane-un-crime-contre-l-humanite 5219546 3232.html

Barbançon, L.-J. (2003). L'Archipel des forçats: Histoire du bagne de Nouvelle-Calédonie, 18631931. Presses Universitaires du Septentrion. https://doi.org/10.4000/books.septentrion.54776

Benton, L. (2009). A search for sovereignty: Law and geography in European empires, 1400-1900. Cambridge University Press. https://doi.org/10.1017/cbo9780511988905

Brévié, J. (1937, December 20). [Lieux de rélégation. Letter addressed to Monsieur le Gouverneur de la Cochinchine. Ref 4724-APA]. Archives nationales d'outre-mer (HCI 694), Aix-en-Provence, France.

Brossard. (1948, May). [Poulo Condore. Taux de prime de capture des évadés. Note addressed to Monsieur le Haut-Commissaire de France pour l'Indochine]. Archives nationales d'outre-mer (2HCI 254), Aix-en-Provence, France.

Brulé, J. (1947). Poulo Condore. Imprimeur des Troupes française d'Extrême Orient (TFEO). Buttin, P. (1948, May 27). [Letter addressed to the Haut Commissaire de France pour l'Indochine]. Archives nationales d'outre-mer (2HCI 254), Aix-en-Provence, France.

Cedile, J. (1946, September 22). [Letter addressed to Monsieur le Président provisoire de la République Cochinchine. Ref 8I-DGC/CAB/AG]. Archives nationales d'outre-mer (HCI 694), Aix-en-Provence, France.

Central Intelligence Agency. (1965, April 19). Vietnam: Current situation report (Central Intelligence Bulletin).

Commissariat Général de France en Indochine. (1953, October 26). FICHE sur les possibilités de l'utilisation de l'archipel de POULO CONDORE. Archives nationales d'outre-mer (INDO HCI 102), Aix-en-Provence, France.

Cornuel, P. (2003). Guyane Française: du "paradis" à l'enfer du bagne. In M. Ferro (Ed.), Le livre noir du colonialisme. XIXe-XXIe siècle: de l'extermination à la repentance (pp. 208-219). Robert Laffont. https://doi.org/10.3917/rhmc.525.0117

Dedebant, C., \& Frémaux, C. (2012). Le bagne des Annamites: Montsinéry-Tonnégrande. L'inventaire.

Demariaux, J.-C. (1956). Les secrets des îles Poulo-Condore: Le grand bagne Indochinois. J. Peyronnet.

Department of State (1970, December 11). Telegram from Secretary of State to American Embassy in Saigon.

Devillers, P. (1988). Paris-Saigon-Hanoi. Les archives de la guerre 1944-1947. Gallimard/Julliard. https://doi.org/10.2307/3769142

Donet-Vincent, D. (1992). La fin du bagne 1923-1953. Éditions Ouest-France. https://doi.org/10.1017/s0395264900052355

Duschinsky, R. (2012). Tabula rasa and human nature. Philosophy, 87(4), 509-529. https://doi.org/10.1017/s0031819112000393

Forster, C. (1996). France and Botany Bay: The lure of a penal colony. Melbourne University Publishing. Foucault, M. (2009). Security, territory, population. Lectures at the College de France, 1977-1978 (G. Burchell, Trans.). Palgrave Macmillan. https://doi.org/10.1177/0263276408097812

Fougère, E. (2002). Île-prison: bagne et deportation. Harmattan. 
Fuggle, S. (2019). A future without prisons? From economies to ecologies of incarceration. Diacritics, 47(1), 28-43. https://doi.org/10.1353/dia.2019.0009

Goscha, C.E. (2011). Historical dictionary of the Indochina war (1945-1954). An international and interdisciplinary approach. Nias Press.

Harkin, T. (1970). The tiger cages of Con Son. Life, 69(3), 26-29.

Haut-Commissaire de France pour l'Indochine. (1946-1949). Problèmes politiques actuels de Poulo-Condore [correspondence]. Archives nationales d'outre-mer (HCI 694), Aix-enProvence, France.

Haut-Commissaire de France pour l'Indochine. (1948, September 18). [Note pour le conseiller politique. Ref $1373 \mathrm{CAB} / \mathrm{V}]$. Archives nationales d'outre-mer (2HCI 254), Aix-en-Provence, France.

Hayward, P., \& Tran, G.T.H. (2014). At the edge: Heritage and tourism development in Vietnam's Con Dao archipelago. Journal of Marine and Island Cultures, 3(2),113-124. https://doi.org/10.1016/j.imic.2014.10.002

Heiner, B. (2015). Excavating the sedimentations of slavery: The unfinished project of American abolition. In G. Adelsberg, L. Guenther, \& S. Zeman (Eds.), Death and other penalties: philosophy in a time of mass incarceration (pp. 13-42). Fordham University. https://doi.org/10.1515/9780823265329-004

Hesse, A. (1925, October 31). [Letter addressed to the Gouverneur Général de l'Indochine. OBJET Régime des détenus politiques. Ref 3072]. Archives nationales d'outre-mer (HCI 694), Aix-en-Provence, France.

Jennings, E. (2001). Vichy in the tropics: Pétain's national revolution in Madagascar, Guadeloupe and Indochina, 1940-1944. Stanford University Press. https://doi.org/10.1086/ahr/107.5.1533

Journal de Saïgon. (1947, March 15). Les anniversaires oubliés. Un peu de géographie.

Kennedy, J. (2014). Decarcerating the punitive society. Federal Sentencing Reporter, 26(4), 263264. https://doi.org/10.1525/fsr.2014.26.4.263

Kothari, U., \& Wilkinson, R. (2010). Colonial imaginaries and postcolonial transformations: exiles, bases, beaches. Third World Quarterly, 31(8), 1395-1412. https://doi.org/10.1080/01436597.2010.538239

Londres, A. (1924). Au bagne. Albin Michel.

Lonely Planet. (2018). Best of Vietnam (2nd ed.). Lonely Planet.

Loyd, J., \& Mountz, A. (2018). Boats, borders, and bases: race, the cold war, and the rise of migration detention in the United States. University of California Press. https://doi.org/10.1525/california/9780520287969.001.0001

Luo, B., \& Grydehøj, A. (2017). Sacred islands and island symbolism in Ancient and Imperial China: an exercise in decolonial island studies. Island Studies Journal, 12(2), 25-44. https://doi.org/10.24043/isj.19

Manos, J.A. (2015). From commodity fetishism to prison fetishism: slavery, convict-leasing, and the ideological productions of incarceration. In G. Adelsberg, L. Guenther, \& S. Zeman (Eds.), Death and other penalties: philosophy in a time of mass incarceration (pp. 4359). Fordham University. https://doi.org/10.2307/j.ctt14jxrhw.7

Marr, D.G. (2013). Vietnam: state, war and revolution (1945-1046). University of California Press. 
McMillan, K. (2019). Contemporary art and unforgetting in colonial landscapes: islands of empire. Palgrave. https://doi.org/10.1007/978-3-030-17290-9 1

Mémoire sur l'isle de Poulo Condor surnommée isle d'Orléans en Chine. (1723). [Memoir attached to letter from Mr Renault, Port-Louis dated 25 July 1723]. Archives nationales d'outremer (COL CI folios 7017), Aix-en-Provence, France.

Michel, D. (1948, February 18). a/s de POULO CONDOR. [Letter to Monsieur le Haut Commissaire de France. Note No $1556 \mathrm{Cab} / \mathrm{G}$ du 16 Février 1948]. Archives nationales d'outre-mer (2HCI 254), Aix-en-Provence, France.

Morlat, P. (1990). La repression coloniale au Vietnam (1908-1940). Harmattan.

Mrázek, R. (2009). Boven Digoel and Terezin: Camps at the time of triumphant technology. East Asian Science, Technology and Society, 3(2-3), 287-314. https://doi.org/10.1007/s12280-009-9099-0

Nash, J. (2016). Do island toponymies exist? Island Studies Journal, 11(2), 339-342.

Nguyễn, D.T. (2012). Côn Đảo Tù̀ Góc Nhìn Lịch Sử. Ho Chi Minh City General Publishing House.

Nguyễn, V.T. (1946, 14 October). [Letter addressed to Monsieur le Commissariat de la République française en Cochinchine. Ref 702-MI/AG]. Archives nationales d'outremer (HCI 694), Aix-en-Provence, France.

Pagès, P.A.M. (1937, March 22). [Régime pénitentiaire en Indochine. Report addressed to the Governeur Général de l'Indochine. Ref 541]. Archives nationales d'outre-mer (HCI 694), Aix-en-Provence, France.

Paterson, L.M. (2016). Prisoners from Indochina in the nineteenth-century French colonial world. In R. Ricci (Ed.), Exile in colonial Asia: kings, convicts, commemoration (pp. 220-247). University of Hawaii Press. https://doi.org/10.21313/hawaii/9780824853747.003.0010

Pierre, M. (2017). Le temps des bagnes. 1748-1953. Tallandier.

Polo, M. (2016). The Travels (N. Cliff, Trans.). Penguin. [Original work published c. 1300 CE]

Ratuva, S. (2019). Contested terrain: reconceptualising security in the Pacific. ANU Press. https://doi.org/10.22459/ct.2019

Roscoe, K. (2018). A natural hulk: Australia's carceral islands in the colonial period, 17881901. International Review of Social History, 63(S26), 45-63. https://doi.org/10.1017/s0020859018000214

Schmitt, C. (2005). Political theology: four chapters of the concept of sovereignty (G. Schwab, Trans). University of Chicago Press. [Original work published 1922]

Sherman, T.C. (2009). From hell to paradise? voluntary transfer of convicts to the Andaman Islands, 1921-1940. Modern Asian Studies, 43(2), 367-388. https://doi.org/10.1017/s0026749x08003594

Shiraishi, T. (1996). The phantom world of Digoel. Indonesia, 61, 93-118. https://doi.org/10.2307/3351365

Stoler, A.L. (2012). Colony. Political concepts: a critical lexicon. https://doi.org/10.2307/j.ctt1xhr6ms.6

Stoler, A.L. (2016). Duress: Imperial durabilities in our times. Duke University Press. https://doi.org/10.2307/j.ctv125jn2s 
Wintrebert, [M]. (1948, December 22). [Project for a letter to Monsieur le Commissaire de la République en Cochinchine]. Archives nationales d'outre-mer (2HCI 254), Aix-enProvence, France.

de Villepoix. (1938, September). L'Archipel des Condores. Revue des Troupes coloniales, 254, 829-852.

Wong, T.-K.D. (2012). The destruction of the British East India Company on Condore Island, 1702-1705. Modern Asian Studies, 46(5), 1097-1115. https://doi.org/10.1017/s0026749x11000424

Zeller, G. (2019). Les cages de la Kempeitaï: Les Français sous la terreur japonaise. Indochine, marsaoût 1945. Tallandier.

Zinoman, P. (2001). The colonial bastille: a history of imprisonment in Vietnam. 1862-1940. University of California Press. https://doi.org/10.1525/9780520925175 